\title{
Sugarcane Bagasse Ash Micronized Using Air Jet Mills for Green Pozzolan in Brazil
}

\author{
Rafael G. D. Molin Filho ${ }^{D},{ }^{1}$ Jaciele M. Rosso, ${ }^{2}$ Eduardo A. Volnistem, \\ Romel D. Vanderlei, ${ }^{3}$ Leda M. S. Colpini, ${ }^{4}$ Mateus M. Ferrer, ${ }^{5}$ Paulo R. Paraíso, ${ }^{1}$ \\ and Luiz M. de M. Jorge ${ }^{1}$ \\ ${ }^{1}$ Department of Chemical Engineering, State University of Maringá, Maringá 87020-900, Brazil \\ ${ }^{2}$ Department of Physics, State University of Maringá, Maringá 87020-900, Brazil \\ ${ }^{3}$ Department of Civil Engineering, State University of Maringá, Maringá 87020-900, Brazil \\ ${ }^{4}$ Campus de Jandaia do Sul, Federal University of Paraná, Jandaia do Sul, 86900-000 Curitiba, Brazil \\ ${ }^{5}$ Department of Physics, Federal University of Pelotas, Pelotas 96010-610, Brazil
}

Correspondence should be addressed to Rafael G. D. Molin Filho; rafagermano@gmail.com

Received 8 January 2019; Revised 21 March 2019; Accepted 5 May 2019; Published 23 May 2019

Academic Editor: Michael Harris

Copyright (C) 2019 Rafael G. D. Molin Filho et al. This is an open access article distributed under the Creative Commons Attribution License, which permits unrestricted use, distribution, and reproduction in any medium, provided the original work is properly cited.

\begin{abstract}
This study provided a basis for new possibilities concerning the use of the sugarcane bagasse ash as a green pozzolanic addition to the Portland cement composite. To that effect, a simple micronization method using air jet milling without any other additional thermal procedure was used to control the characteristics of ash particles. This procedure not only maintains the required characteristics of the residues but can also improve some of them. Sugarcane bagasse ash is a residue produced on large scale in Brazil by ethanol and sugar plants as a result of the burning of sugarcane bagasse in energy cogeneration. The residue used in this study was initially characterized by scanning electron microscopy, granulometric and specific mass analyses, $\mathrm{N}_{2}$ adsorption measurements, X-ray diffraction, X-ray fluorescence spectroscopy, and thermogravimetric analysis with differential thermal analysis. Pozzolanic ash activity was evaluated according to the axial compressive strength at 28 days and the modified Chapelle methods. The results showed that the milling fly sugarcane bagasse ash samples presented satisfactory pozzolanic activity.
\end{abstract}

\section{Introduction}

The prospect of an increase in Portland cement consumption indicates that by 2025 the release of $\mathrm{CO}_{2}$ from cement production processes will be as much as 3.5 billion tons per year worldwide. Shi et al. [1] argue that this projection equates to all $\mathrm{CO}_{2}$ production from industrial activities in Europe at the beginning of the current decade. According to Mehta and Monteiro [2], the annual generation of at least 1.5 billion tons of $\mathrm{CO}_{2}$ resulting from Portland cement manufacture accounts for approximately $7 \%$ of global emissions. Furthermore, the cement industry is the second largest consumer of industrial energy, accounting for $7 \%$ of the consumption [3].

On the other hand, a joint report issued by the International Energy Agency (IEA) and the Cement
Sustainability Initiative (CSI) states that the implementation of changes, along with the development of processes and the support of public policies, will allow for a $24 \%$ reduction in the levels of $\mathrm{CO}_{2}$ generated as a result of cement production by 2050 [3]. According to Mehta [4], one of the main contributions to scale down energy consumption and the greenhouse effect is the reduction of cement production processes from raw clinker lumps.

The development of green pozzolanic binders to partially replace Portland cement is a valuable socioenvironmental option. As reported by $\mathrm{Yu}$ et al. [5], 80\% of fly ashes were successfully used in Portland cement production. In this study, the authors emphasized the valuable reduction in cost, energy consumption, and $\mathrm{CO}_{2}$ emissions when compared to conventional concretes. Loh et al. [6] emphasize the versatile use of sugarcane bagasse and its by-products as a green raw 
material in several composites. According to them, the low pollutant index is one of the highlights of the use of green materials to develop new solutions. Among the new options of green pozzolanic addition under development, the milling fly sugarcane bagasse ash (MFSCBA) stands out, as reported by Soares et al. [7], Cordeiro et al. [8], Delalibera et al. [9], and Bahurudeen and Santhanam [10].

The sugarcane bagasse ash (SCBA) is a residue resulting from the burning of sugarcane bagasse in boilers in power cogeneration processes in sugar plants. The term SCBA represents all ashes generated, that is, the fly sugarcane bagasse ash (FSCBA) from gas washing and the bottom sugarcane bagasse ash (BSCBA) from the burning of the boiler's bottom. FSCBA milling results in MFSCBA. The current processing technology allows all the energy required to operate plant processes (steam, mechanical, and electrical) to be supplied by this cogeneration system, which may lead to energy self-sufficiency in plants $[11,12]$. Furthermore, in some cases, plants partner up with power distribution companies to even provide electric power to consumer units connected to the power grid. All these factors put together stress the valuable contribution of the reuse of by-products resulting from the burning of bagasse in electric power production.

In addition, Fairbairn et al. [13] showed that the use of MFSCBA as a pozzolanic material would reduce $\mathrm{CO}_{2}$ emissions along the cement production chain, enabling the issue of the certified emission reduction (CER) credits. In the referred study, the authors highlighted the possibility of reducing 519.3 thousand tons of $\mathrm{CO}_{2}$ yearly, given the potential of SCBA generation in the region studied, which is responsible for $60 \%$ of the sugarcane production in Brazil.

Based on the data provided by Hojo [14], it is possible to estimate that $11 \%$ of the ashes generated in boilers are FSCBA-type resulting from gas and suspended particulate matter washing, whereas $89 \%$ of the ashes are BSCBA-type resulting from removing particulates from the bottom of boilers.

Brazil is considered to be the largest sugarcane producer in the world and the main exporter of its derivatives, namely, ethanol and sugar. According to the data from Fiesp/Ciesp [15], in general, 0.260 tons of sugarcane bagasse is generated for each ton of sugarcane processed, producing $6.2 \mathrm{~kg}$ of ashes. According to Conab [16], the Brazilian sugarcane production for the 2018/2019 harvest is estimated to be around 615 million tons. These results show that Brazil can potentially produce up to 3.813 million tons of SCBA (FSCBA + BSCBA) in the referred harvest. SCBA is currently mainly disposed of directly in farmlands, with no effective value being added to the soil and pushing up logistics costs which make sugar plant outputs more expensive.

For FSCBA to be ready to be used as pozzolana, a number of prerequisites provided by Brazilian standard NBR 12653 [17] and international standard ASTM C618-17a [18] must be met, as well as prerequisites related to the amorphous structural organization $[7,8,10,19,20]$. Ash milling, bagasse burning control, or even ash burning control can be mentioned as the most commonly used preparation methods. In this situation, it is known that particle size and shape have a significant effect on the viability of Portland cement-based materials [21].

In this sense, FSCBA micronization by air jet mills is a relevant technique that allows microstructural alterations. This application has been used efficiently in other industrial segments, such as mineral milling, pharmaceuticals, and the food industry [22]. Micronization parameterization performed in the laboratory has a simplified set-up, allowing for large-scale production in industrial air jet mills.

The ash was prepared without using any additional burning processes, with thermal control in the laboratory. This study assessed the efficacy of the innovative micronization process of fly sugarcane bagasse ash using air jet mills to obtain and prepare pozzolanicity prerequisites. The performance of pozzolanic materials of milling fly sugarcane bagasse ash was also analyzed using the compressive strength method as well as the chemical reactivity analysis method.

\section{Materials and Methods}

2.1. Materials. The characterized materials later used in the development of the pozzolanic analyses were as follows:

(1) Cement CP II F 32 as per Brazilian standards NBR 7215 [23] and NBR 11578 [24]. Cement chemical composition was as follows: $66.1 \% \mathrm{CaO} ; 15.5 \% \mathrm{SiO}_{2}$; 4.94\% $\mathrm{MgO} ; 4.1 \% \mathrm{SO}_{3} ; 3.72 \% \mathrm{Al}_{2} \mathrm{O}_{3} ; 3.13 \% \mathrm{Fe}_{2} \mathrm{O}_{3}$; $1.1 \% \mathrm{~K}_{2} \mathrm{O} ; 0.369 \% \mathrm{Na}_{2} \mathrm{O} ; 0.272 \% \mathrm{TiO}_{2} ; 0.226 \% \mathrm{SrO}$; $0.131 \% \mathrm{P}_{2} \mathrm{O}_{5} ; 0.0802 \% \mathrm{MnO} ; 0.0058 \% \mathrm{ZnO}$; and $0.3151 \%$ of other compounds. The content of carbonate materials was between $6 \%$ and $10 \%$. Insoluble residues represented less than $2.5 \%$. The initial setting time was $1 \mathrm{~h}$. The specific area was larger than $260 \mathrm{~m}^{2} / \mathrm{kg}$.

(2) Brazilian standard sand was provided by the Technological Research Institute (IPT-SP), according to the specifications provided by Brazilian standard NBR 7214 [25]. Four standard fractions (retained on the sieve) were used: coarse $(1.2 \mathrm{~mm}$ to $2.4 \mathrm{~mm}$ ), medium coarse $(0.6 \mathrm{~mm}$ to $1.2 \mathrm{~mm})$, medium fine $(0.3 \mathrm{~mm}$ to $0.6 \mathrm{~mm})$, and fine $(0.15 \mathrm{~mm}$ to $0.3 \mathrm{~mm})$.

(3) Glenium 51 was obtained from the manufacturer BASF. It is classified as a third-generation polycarboxylic ether-based chemical additive with total water solubility. The additive is white and cloudy in appearance and was used in its liquid state, with a solid content of $28.5 \%$ to $31.5 \%$, pH between 5 and 7 , viscosity of $<150$ (cps), and density of $1.067 \mathrm{~g} / \mathrm{cm}^{3}$ to $1.107 \mathrm{~g} / \mathrm{cm}^{3}$.

(4) The water used was in compliance with Brazilian standard NBR 15900-1 [26].

(5) The fly ashes were collected in a plant located in the city of Paranacity, Brazil (latitude $22^{\circ} 55^{\prime} 48^{\prime \prime}$ S/longitude $\left.52^{\circ} 09^{\prime} 04^{\prime \prime} \mathrm{W}\right)$. The type of sugarcane used was RB867515, and sandy soil (Caiuá sandstone) is predominant in the land used to cultivate this plant in the region where the sugar plant operates $(30 \mathrm{~km}$ 
radius). Mechanized harvesting accounts for over $95 \%$ of all the sugarcane harvested. Similarly to Hojo's study [14], fly ashes represent $11 \%$ of the ashes generated in the sugar plant.

\subsection{FSCBA Preparation and Characterization Methods.} The fly sugarcane bagasse ash generated from the burning of sugarcane bagasse in the boiler, at temperatures between $500^{\circ} \mathrm{C}$ and $800^{\circ} \mathrm{C}$, only underwent sieving separation, chamber drying, and air jet milling. It is important to stress that the FSCBA was collected separately in dedicated intermediate tanks at the exit of the gas and particulate washing process, that is, prior to being mixed to the BSCBA in the settling tanks. Altogether, four $5 \mathrm{~kg}$ fractions of wet material (approximately 10\% water content) were collected in four consecutive days. The fractions were manually mixed to make up the sample to be analyzed.

FSCBA raw-state samples were chamber-dried at $100 \pm 5^{\circ} \mathrm{C}$ for 24 hours. Subsequently, the samples were manually sieved ( $2 \mathrm{~mm} \cdot \mathrm{mesh})$ to remove larger impurities, such as the remaining organic straws resulting from the incomplete burning. This initial procedure generated the primary type of FSCBA.

After sieving, the ash was milled and homogenized by air jet milling to generate the MFSCBA samples. Particle micronization consisted in particle collisions that took place inside a steel-resistant chamber, which occurred after compressed air was applied at up to $500 \mathrm{~m} / \mathrm{s}$ for $10 \mathrm{~min}$. The air jet milling process was performed in laboratory-scale equipment, with an air pressure injection of $0.8 \mathrm{MPa}$, output particle size of 1 to $45 \mu \mathrm{m}$, and production capacity of $500 \mathrm{~g}$ to $5000 \mathrm{~g}$ of material milled per hour. The first stage in the air jet milling process created suction to aspirate light materials within the chamber which removed lighter organic matter exposed on the upper part of the sample. With the process used, ash conversion efficiency was 95\%. Figure 1 shows a scheme of the micronization equipment operation. The second stage of the procedure was intended to achieve the necessary size reduction to enable pozzolanic investigations.

The methods used in FSCBA and MFSCBA characterizations were as follows:

(1) Scanning electron microscopy (SEM): generation of visual aspects and textural indication. The samples were fixed on to the surface of a double-faced carbon adhesive tape and coated with a thin gold layer. The analyses were performed in a FEI microscope, Quanta 250 model.

(2) Granulometric analysis: evaluation of the granulometric classes by sieving with sedimentation analysis as per NM 248 [27].

(3) Granulometric analysis with laser refraction analyzer.

(4) Specific mass: evaluated as per the NM 52 [28].

(5) X-ray diffraction (XRD): structural characterization of the samples and identification of the presence or absence of secondary phases. The equipment used was a Shimadzu, XRD 6000 model with a Cuk $\alpha$

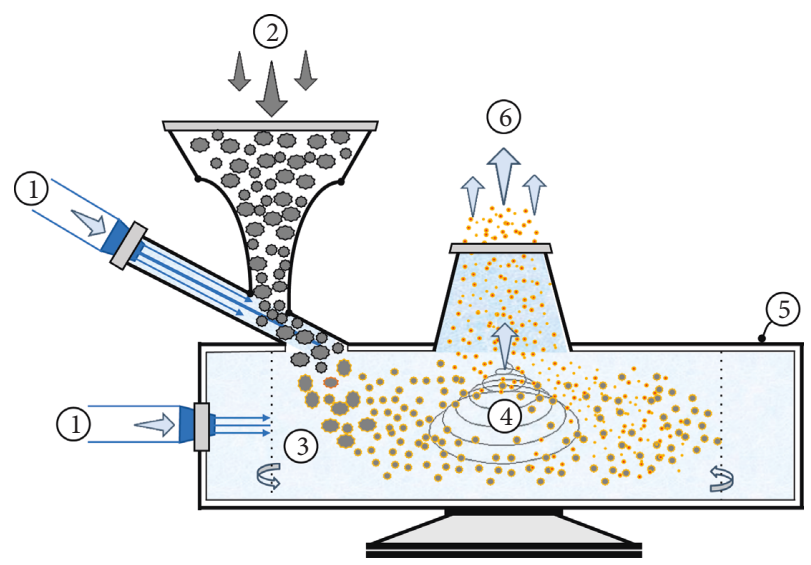

FIgURE 1: Schematic illustration of the air jet milling process. 1, compressed air (feeding); 2, feed funnel; 3, compressed air (milling); 4 , milling chamber; 5 , steel structure of air jet mills; 6 , micronized product (outlet).

source with $40 \mathrm{kV}$ and $30 \mathrm{~mA}$, scan speed of $1^{\circ} \mathrm{min}^{-1}$, and range of $4^{\circ} \leq 2 \theta \leq 90^{\circ}$.

(6) X-ray fluorescence spectroscopy (XRF): chemical compounds quantification. The equipment used was a Rigaku, ZSX mini II model.

(7) Thermogravimetric analysis with differential thermal analysis (TGA/DTA): analysis of the mass variation along the temperature exposure and phase transition behavior. The equipment used was a Netzsch, STA 409 PG/4/G Luxx model.

2.3. Pozzolanic Investigation Methods. MFSCBA preparations followed the recommendations provided in Brazilian standard NBR 12653 [17] and international standard ASTM C618-17a [18]. Mortar preparations, the flow value of the control mortar test, the chemical reactivity test for MFSCBA, and the compressive strength analysis followed the guidelines provided by Brazilian standards NBR 5752 [29] and NBR 15895 [30], which directly correlated to international standards ASTM C109/C109M-12 [31], ASTM C1437-7 [32], and ASTM C311-11b [33]. In addition, publications by authors who have addressed the theme were also considered $[7,8,10,19,20,34]$.

The percentages of alkalis $\left(\mathrm{Na}_{2} \mathrm{O}\right.$ and $\left.\mathrm{K}_{2} \mathrm{O}\right)$ were calculated based on the NM 25 [35] standard. The pozzolanic studies were conducted using two methods: the first one evaluated the pozzolanic performance of the SCBA with Portland cement by analyzing the axial compressive strength at 28 days, by means of the IDP28 indicator described in the NBR 5752 [29] standard, replacing 25\% of the cement mass for SCBA mass. The second pozzolanic analysis method, described in the NBR 15895 [30] standard and referred to as the modified Chapelle method, was used to analyze the chemical reactivity of SCBA with lime and was quantified by means of the $\mathrm{I}_{\mathrm{Ca}(\mathrm{OH}) 2}$ indicator.

2.4. Determining the Pozzolanic Performance Index with Portland Cement at 28 Days. In general, the NBR 12653 [17] 
standard determines that to be classified as a pozzolanic material, the Pozzolanic Activity Index of the material studied with the Portland cement (IDP28) should be at least $90 \%$. This method evaluates the axial compressive strength at 28 days of specimens in which $25 \%$ of the cement mass is substituted for the mass of the studied material. As described in the NBR 5752 [29] standard, the mean axial compressive strength of CP II-F-32 cement mortar was evaluated on day 7 for six cylindrical specimens $(\mathrm{CSs})(50 \mathrm{~mm} \times 100 \mathrm{~mm})$. Thus, two mortar compositions were prepared (in duplicate): one reference sample without MFSCBA (Mref), and another with MFSCBA (Mmf). For each sample class, six cylindrical specimens $(50 \mathrm{~mm} \times 100 \mathrm{~mm})$ were prepared to rupture at 28 days by axial compressive strength in a 100 -ton capacity hydraulic press. The materials used in mortar compositions were cement $(624 \pm 0.4 \mathrm{~g})$, sand $(1872 \pm 0.4 \mathrm{~g})$, and water $(300 \pm 0.2 \mathrm{~g})$. As for the Mmf mortar, $25 \%$ of the cement mass was replaced for an equivalent mass of MFSCBA, in addition to occasional workability-related corrections made with the use of superplasticizer. These doses represent a water/cement factor of 0.48 and a sand/cement factor of 3 .

The following equipment was used in mortar preparation: a $1000 \pm 0.05 \mathrm{~g}$ analytical balance, an automated mortar mixer operating at low speed at $140 \pm 5 \mathrm{rpm}$ and high speed at $285 \pm 10 \mathrm{rpm}$, and a 5 -liter flow table used in the consistency index test. Mortar mixtures were performed according to the NBR 7215 [23] standard. The Mmf consistency index (CI) was accepted with a $\pm 10 \mathrm{~mm}$ variation in relation to the Mref CI.

For the axial compressive strength results to be accepted in IDP28 calculations, the existence of patterns between the means of both replicate batches is expected. Thus, Student's $t$ test for the mean strength of both samples was performed. The central hypothesis assumed in this test was that the difference of the means of each sample is zero, i.e., $h_{0}=0$. To that effect, the existence of equivalent variances with $2 n-2$ freedom degrees and 95\% reliability level [36] were considered. Equation (1) was used to calculate the pozzolanic coefficient.

$$
\text { IDP28 }=\frac{f_{\mathrm{c}_{\mathrm{Mmf}}}}{f_{\mathrm{c}_{\mathrm{Mref}}}} \times 100,
$$

where IDP28 is the performance index percentage of the studied material with the Portland cement at 28 days; $f_{\mathrm{c}_{\mathrm{Mmf}}}$ is the compressive strength mean of Mmf specimens at 28 days, in $\mathrm{MPa}$; and $f_{\mathrm{c}_{\mathrm{Mref}}}$ is the compressive strength mean of Mref specimens at 28 days, in $\mathrm{MPa}$.

Finally, a complementary visual microstructural evaluation in areas with cement paste crystallizations was performed by scanning electron microscopy with energy-dispersive X-ray spectroscopy (SEM/EDS) at 28 days. The points in the EDS reading came from fragments no larger than $8 \mathrm{~mm}$ mainly located in the central area of the ruptured specimens. The samples were metalized with gold ink on a carbon tape.

2.5. Pozzolanic Activity Index Using the Modified Chapelle Method. The method described in the NBR 15895 [30] standard is an adaptation of Raverdy et al. [37]. Generally, the test used to conduct a pozzolanic activity analysis determines the content of calcium hydroxide $\left(\mathrm{Ca}(\mathrm{OH})_{2}\right)$ produced, in milligrams ( $\mathrm{mg}$ ) per gram $(\mathrm{g})$, by the studied material (supposedly pozzolanic).

Equation (2) presents the Chapelle theoretical model for the pozzolanic activity index recommended in the NBR 15895 [30] standard.

$$
\mathrm{I}_{\mathrm{Ca}(\mathrm{OH})_{2}}=\frac{28 \times\left(V_{3}-V_{2}\right) \times F_{\mathrm{c}}}{m_{2}} \times 1.32,
$$

where $\mathrm{I}_{\mathrm{Ca}(\mathrm{OH})_{2}}$ is the Chapelle pozzolanic activity index, expressed according to the $\mathrm{Ca}(\mathrm{OH})_{2}$ content of the material studied, in milligrams per gram; $m_{2}$ is the mass of the studied material, in grams; $V_{2}$ is the $\mathrm{HCl} 0.1 \mathrm{M}$ volume, in milliliters; $V_{3}$ is the $\mathrm{HCl} 0.1 \mathrm{M}$ volume in blank solution, in milliliters; $F_{c}$ is the $\mathrm{HCl}$ correction factor for a concentration of $0.1 \mathrm{M}$; and 1.32 is the molecular reaction $\mathrm{Ca}(\mathrm{OH})_{2}$ per $\mathrm{CaO}$.

According to Raverdy et al. [37], the minimum consumption value of $330 \mathrm{mg}$ of $\mathrm{CaO}$ per gram of the evaluated material is expected, and stoichiometry results determined that this value accounts for $436 \mathrm{mg}$ of $\mathrm{Ca}(\mathrm{OH})_{2}$ per gram.

The analyses were performed in duplicate using two individual readings per test. Thus, the average results and standard deviations of $\mathrm{I}_{\mathrm{Ca}(\mathrm{OH}) 2}$ indices were calculated considering a total of four results. Lastly, the confidence interval was estimated by Student's $t$-test, with a $5 \%$ significance level for reproducibility verification.

\section{Results and Discussion}

3.1. Characterization of the Materials Used. According to the tests performed to determine the specific mass, the MFSCBA presented values of $2.52 \mathrm{~g} / \mathrm{cm}^{3}$. The specific mass of the fly sugarcane bagasse ash reported by Cordeiro et al. [8] of $2.569 \mathrm{~g} / \mathrm{cm}^{3}$ was close to the MFSCBA sample. Della et al. [38] emphasize that the lower specific mass of fly sugarcane bagasse ashes results from a greater quantity of pores as compared to the BSCBA. Figure 2 shows the visual images and micrographs of FSCBA and MFSCBA samples.

The FSCBA (Figure 2(a)) and MFSCBA (Figure 2(b)) images were made with an approximation of $100 \mathrm{x}$ and $5000 x$, respectively, in order to provide a clearer image due to the micronization process.

Therefore, Figure 2 shows the efficiency of air jet milling in micronization. The fragments and irregularities of the faces in their most varied forms are characteristics of this type of process, in which collisions and friction are agents that promote grain size reduction. Figure 3 shows the granulometric patterns and X-ray diffraction (DRX) patterns of the FSCBA and MFSCBA categories.

Figure 3(a) shows that both FSCBA samples have the largest particle representation in the range of $0.1 \mathrm{~mm}$ to $0.3 \mathrm{~mm}$, which account for at least $70 \%$ of them, the majority being smaller than $0.7 \mathrm{~mm}$. The results show the efficiency in reducing ash particle size using air jet milling. As for the MFSCBA sample, $98 \%$ of the particles were reduced to a size smaller than $0.02 \mathrm{~mm}(20 \mu \mathrm{m})$. In addition, all particles are smaller than $0.03 \mathrm{~mm}(30 \mu \mathrm{m})$. Therefore, the micronization method using air jet milling, in fact, presented great efficiency in particle size reduction. The granulometry obtained 


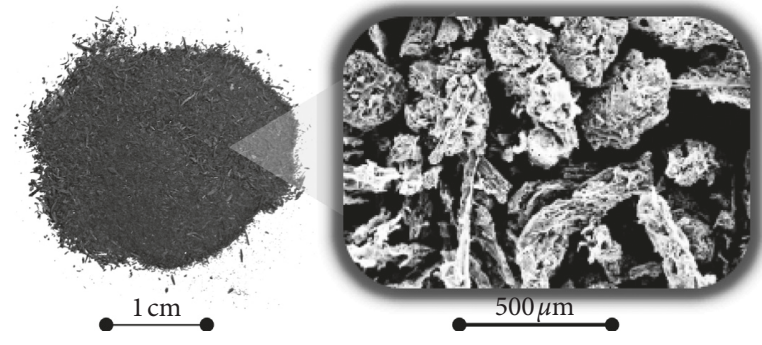

(a)

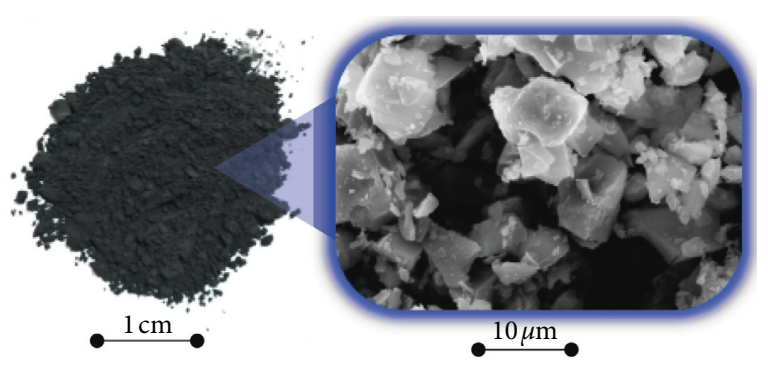

(b)

FIgURE 2: Visual aspects and SEM micrographs of fly sugarcane bagasse ash samples. (a) FSCBA and (b) MFSCBA.

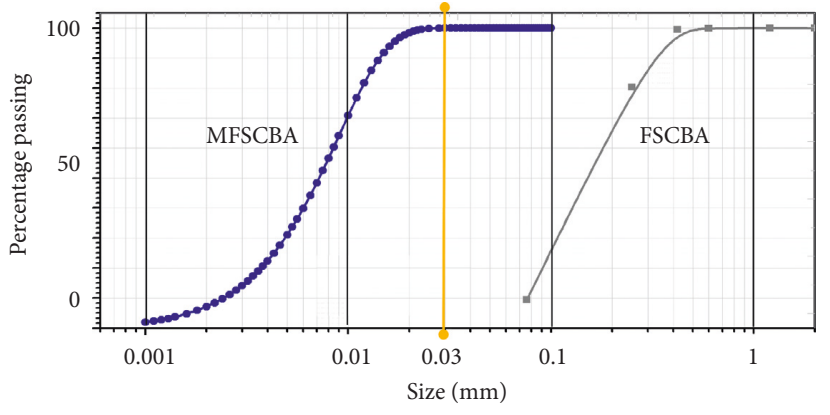

(a)

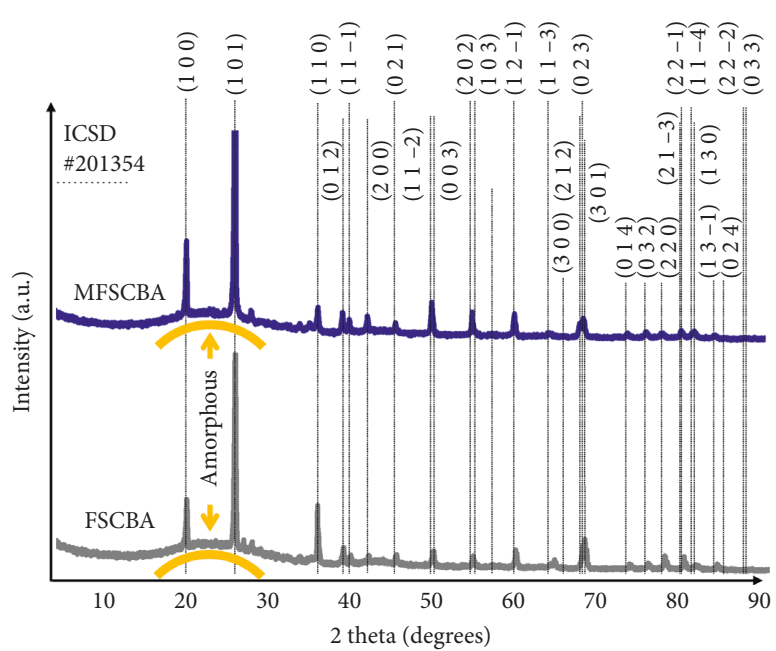

(b)

FIGURE 3: Granulometric curves of fly sugarcane bagasse ash samples and X-ray diffraction (DRX) patterns. (a) Granulometric curves of MFSCBA and FSCBA samples and (b) DRX patterns of MFSCBA and FSCBA samples.

in this method is in accordance with the requirements described in Table 1.

Figure 3(b) shows that all samples present diffraction patterns of alpha-quartz structure (standard pattern number \#201354-ICSD database) as a priority pattern [39]. This pattern is the same presented by Filho et al. [40] for a sample from a Brazilian plant. The samples presented an elevation of the baseline in a range between $15^{\circ}$ and $35^{\circ}$, which also indicates the presence of an amorphous phase.

Table 2 shows the chemical composition of the milled fly sugarcane bagasse ash.

Table 2 shows that the MFSCBA sample presents silicon dioxide $\left(\mathrm{SiO}_{2}\right)$ as the compound with higher representativity. In addition to $\mathrm{SiO}_{2}$, there are four other oxides with percentages higher than $5 \%$ and four other oxides with percentages higher than $1 \%$. Silicon dioxide, iron dioxide, and aluminum dioxide, together with calcium dioxide, can also be observed with good representativity in milling fly sugarcane bagasse ash samples in other studies $[7-9,14]$.

3.2. Evaluation of MFSCBA as a Pozzolanic Material. Table 1 shows the list of characterization results obtained for the MFSCBA sample. As per Brazilian standard NBR 12653
[17], the milling fly sugarcane bagasse ash is an artificial $\mathrm{E}$ class pozzolan resulting from industrial transformation processes.

The MFSCBA sample did not satisfy all prerequisites. However, although the loss on ignition has exceeded standard recommendations, it is lower than the $17.6 \%$ found in the sample investigated by Lima and Rossignolo [41] and close to the $11.9 \%$ reported by Cordeiro et al. [8] .

Lima and Rossignolo [41] used a sample of ash as a pozzolan with $18.02 \%$ alkali content. The authors argued that even though this is a significant percentage, it does not represent more than the $0.6 \%$ of limit of the total concrete mass. The cement used in this study is estimated to have only $1.1 \%$ alkali content. Replacing the cement mass for $25 \%$ of MFSCBA would produce a cement compound with $2.18 \%$ alkali content. This percentage would represent only $0.48 \%$ of the total mass of mortars as the ones dosed in this study. Such alkali percentage would be even less in concretes, given the presence of gravel.

3.3. Determining the Pozzolanic Performance Index with Portland Cement at 28 Days. The result of the mean axial compressive strength at 7 days for Mref was $21.4 \mathrm{MPa}$ with 
TABle 1: Prerequisites, methods, and results of MFSCBA characterization.

\begin{tabular}{|c|c|c|c|c|}
\hline & Prerequisites & $\begin{array}{l}\text { Class E artificial pozzolan } \\
\text { [17] }\end{array}$ & Methods [17] & $\begin{array}{l}\text { Results for } \\
\text { MFSCBA }\end{array}$ \\
\hline 1 & $\mathrm{SiO}_{2}+\mathrm{Al}_{2} \mathrm{O}_{3}+\mathrm{Fe}_{2} \mathrm{O}_{3}$ (\% min.) & 50 & X-ray fluorescence spectroscopy (XRF) & 74.15 \\
\hline 2 & $\mathrm{SO}_{3}(\% \max )$. & 5 & X-ray fluorescence spectroscopy (XRF) & 1.2 \\
\hline 3 & Moisture content (\% max.) & 3 & $\begin{array}{l}\text { Thermogravimetric analysis and moisture } \\
\text { control }\end{array}$ & In accordance $\mathrm{a}^{\mathrm{a}}$ \\
\hline 4 & Loss on ignition (\% max.) & 6 & Thermogravimetric analysis (TGA) & $13.28^{\mathrm{b}}$ \\
\hline 5 & Alkalis (\% max.) & 1.5 & $\begin{array}{l}\text { X-ray fluorescence spectroscopy (XRF and } \\
\text { NBR NM } 25 \text { (2003)) }\end{array}$ & $5.4^{\mathrm{b}}$ \\
\hline 6 & $\begin{array}{c}\text { Amount of particles smaller than } 0.045 \mathrm{~mm} \\
\text { (\% min.) }\end{array}$ & 80 & $\begin{array}{l}\text { Air jet milling process and measurement by } \\
\text { laser refraction analyzer }\end{array}$ & 100 \\
\hline 7 & $\begin{array}{c}\text { Structural organization with amorphous } \\
\text { indication }\end{array}$ & Indication & $\mathrm{X}$-ray diffraction (XRD) & In accordance ${ }^{\mathrm{a}}$ \\
\hline
\end{tabular}

${ }^{a}$ The moisture content was controlled and checked considering mortar production. ${ }^{\mathrm{b}}$ Off-specification requirements.

TABLE 2: Chemical composition of the milled fly sugarcane bagasse ash sample.

\begin{tabular}{lcc}
\hline & Elements & MFSCBA (\%) \\
\hline 1 & $\mathrm{SiO}_{2}$ & 60.833 \\
2 & $\mathrm{~K}_{2} \mathrm{O}$ & 8.104 \\
3 & $\mathrm{Fe}_{2} \mathrm{O}_{3}$ & 7.754 \\
4 & $\mathrm{CaO}$ & 7.744 \\
5 & $\mathrm{Al}_{2} \mathrm{O}_{3}$ & 5.563 \\
6 & $\mathrm{P}_{2} \mathrm{O}_{5}$ & 3.932 \\
7 & $\mathrm{TiO}_{2}$ & 1.771 \\
8 & $\mathrm{MgO}$ & 1.571 \\
9 & $\mathrm{SO}_{3}$ & 1.401 \\
10 & $\mathrm{MnO}$ & 0.704 \\
11 & $\mathrm{Cl}$ & 0.355 \\
12 & $\mathrm{SrO}$ & 0.074 \\
13 & $\mathrm{Na}_{2} \mathrm{O}$ & 0.058 \\
14 & $\mathrm{Cr}_{2} \mathrm{O}_{3}$ & 0.048 \\
15 & $\mathrm{ZnO}_{10}$ & 0.036 \\
16 & $\mathrm{ZrO}_{2}$ & 0.033 \\
17 & $\mathrm{CuO}$ & 0.007 \\
& $\mathrm{Others}^{2}$ & 0.012 \\
\hline
\end{tabular}

maximum relative deviation (MRD) of $2.4 \%$, in accordance with the $6 \%$ limit required as per NBR 7215 [23]. All mortars obtained the expected CI of $20 \mathrm{~cm} \pm 1$. The Mmf required the use of a superplasticizer (0.5\%) in both preparations to correct the CI. The existence of unitary mass values around a level of $2 \mathrm{~g} / \mathrm{cm}^{3}$ is observed. Such values are consistent with the mortars used in the research by Filho et al. [40]. The specimens were molded after calculating the Mmf CI.

The axial compressive strength values in MPa described in Table 3 show the results of six specimens. Table 3 also shows the statistical indicators of Student's $t$-test related to the mean of both samples.

The results of the mean compression for Mmf samples are $20 \%$ greater than the mean of Mref results. The results of the mean compressive strength at 28 days for Mref (Table 3) are similar to the ones obtained by Filho [42], which was 25.14 MPa, and by Lima and Rossignolo [41], which was 27.19 MPa, using high initial strength cements CP V-ARI. In addition, Filho [42] used sand of the same origin and specifications as the one used in this study.
TABLE 3: Axial compressive strength and statistical indicators of mortars.

\begin{tabular}{|c|c|c|c|c|}
\hline \multirow{2}{*}{$\begin{array}{l}\text { Specimens by batches and } \\
\text { statistical indicators }\end{array}$} & \multicolumn{4}{|c|}{$\begin{array}{l}\text { Compressive strength } \\
\text { indices }(\mathrm{MPa})\end{array}$} \\
\hline & $\mathrm{Mref}_{1}$ & $\mathrm{Mref}_{2}$ & $\mathrm{Mmf}_{1}$ & $\mathrm{Mmf}_{2}$ \\
\hline CS1 & 26.5 & 25.6 & 34.1 & 31.2 \\
\hline CS2 & 27.1 & 26.5 & 31.8 & 34.6 \\
\hline CS3 & 27.3 & 29.7 & 34.2 & 30.1 \\
\hline CS4 & 28.4 & 25.2 & 31.5 & 34.0 \\
\hline CS5 & 26.0 & 24.8 & 29.5 & 29.7 \\
\hline CS6 & 25.9 & 24.9 & 29.4 & 29.7 \\
\hline $\begin{array}{l}\text { Maximum relative } \\
\text { deviation (MRD) }\end{array}$ & 4.9 & 14.3 & 7.8 & 7.4 \\
\hline Variance & 0.88 & 3.46 & 4.53 & 4.99 \\
\hline Observations & 6 & 6 & 6 & 6 \\
\hline Mean & \multicolumn{2}{|c|}{26.5} & \multicolumn{2}{|c|}{31.7} \\
\hline Mean variance & \multicolumn{2}{|c|}{2.17} & \multicolumn{2}{|c|}{4.76} \\
\hline Null hypothesis $\left(h_{0}\right)$ & \multicolumn{2}{|c|}{0} & \multicolumn{2}{|c|}{0} \\
\hline Degrees of freedom (DF) & \multicolumn{2}{|c|}{10} & \multicolumn{2}{|c|}{10} \\
\hline Stat $t$ & \multicolumn{2}{|c|}{0.88} & \multicolumn{2}{|c|}{0.16} \\
\hline$P(T \leq t)$ one-tailed & \multicolumn{2}{|c|}{0.20} & \multicolumn{2}{|c|}{0.44} \\
\hline Critical $t$ one-tailed & \multicolumn{2}{|c|}{1.81} & \multicolumn{2}{|c|}{1.81} \\
\hline$P(T \leq t)$ two-tailed & \multicolumn{2}{|c|}{0.40} & \multicolumn{2}{|c|}{0.88} \\
\hline Critical $t$ two-tailed & \multicolumn{2}{|c|}{2.23} & \multicolumn{2}{|c|}{2.23} \\
\hline
\end{tabular}

Compressive strength values for $\mathrm{Mmf}$ are significantly higher than those obtained by Filho [42], which was $15.65 \mathrm{MPa}$ at 28 days for his mortar with $26 \%$ of the cement being replaced for ash. The strength results (concrete specimens) of Delalibera et al. [9], which were about $20 \mathrm{MPa}$ (rich trace) at 28 days, for an estimated trace with $25 \%$ of the cement replaced for MFSCBA, are lower than those obtained in this research.

According to Table 3, in all cases, the statistics of the test (Stat $t$ ) was within the $95 \%$ confidence interval both in the one-tailed test (below the critical $t$ ) and the two-tailed test (ranges between critical $-t$ and critical $+t$ ), assuming the hypothesis $\mathrm{h}_{0}$. The $p$ value $(P(T \leq t))$ higher than the evaluated significance value $(\alpha)$ of $0.05(5 \%)$, in all cases, is another statistical evidence that both batches produce means with repeatability guarantee. Therefore, the results of the means can be used with $95 \%$ confidence to estimate the mean result of both test batches. The triplicate was not performed due to the satisfactory results of the duplicates. 
Considering the acceptance conditions of compressive strength analyses of the batches, the pozzolanic performance index of the ash with Portland cement (IDP28) was obtained by using equation (1) from the result of the mean compressive strength. The Mmf obtained IDP28 was $120 \%$.

It is noteworthy that the Mmf IDP28 result was satisfactorily reached with a performance that increased the mean mortar strength by $20 \%$ when compared to Mref. In addition, this result preliminarily indicates the probable existence of reactivity in oxides with $\mathrm{Ca}(\mathrm{OH})_{2}$ in the presence of water, especially in regard to the $\mathrm{SiO}_{2}$ presented in the MFSCBA in the amorphous state, to form hydrated calcium silicate.

Figures 4(a) and 4(b) show the visual aspects of the mortar specimens. Figures 4(c) and 4(d) present the internal structure images obtained via SEM/EDS of the ruptured mortars at 28 days, as well as the points of measurement of the dispersive energy in specimen fragments.

A difference in color among the sample specimens can be observed. The Mmf sample (Figure 4(b)) presented a darker color, similar to the coloration of the MFSCBA sample itself (Figure 2(b)).

As complementary results in Figure 4, EDS data in both Figures 4(e) and 4(f) show a similar Ca and Si ratio, as it was expected. Value deviations regarding the percentages shown in the table occurred because carbon and oxygen percentages were maintained during measurement and are not considered reliable values to be used for comparison purposes. There is no significant difference related to the association of these compounds between mortars; thus, it is possible to assume that Mmf kept at least the same level of formation of the main crystals obtained in the Mref. In the Mref (Figure 4(c)), it is possible to observe the presence of the crystals, which include formations which suggest the presence of calcium hydroxide, calcium silicate hydrate, cristobalite, calcium monosulfate, and ettringite, among others, similar to those reported by Mehta and Monteiro [2], Kazmi et al. [34], and Melo [43]. Moreover, Mref samples presented the largest cracks and voids in the agglomerates when compared to the other samples.

However, the Mmf aspect, especially regarding the formation of continuous plate on large scale with reduction of capillary voids, as mentioned by Mehta and Monteiro [2], was highlighted in the SEM analysis. This could be a probable consequence of the pozzolanic effect attributed to the system, as it was observed by Kazmi et al. [34] and Melo [43]. The reduced amount of capillary voids, the cohesive extension of the plates (Figure $4(\mathrm{~d})$ ), and their forms are possibly related to the $20 \%$ increase in Mmf strength when compared to the Mref.

\subsection{Pozzolanic Activity Indices Using the Modified Chapelle} Method. The results obtained for the chemical reactivity indicator were 604 and $596 \mathrm{mg}$ of $\mathrm{Ca}(\mathrm{OH})_{2}$ per gram for the first batch and 604 and $625 \mathrm{mg}$ of $\mathrm{Ca}(\mathrm{OH})_{2}$ per gram for the second batch. Thus, the average result of all values in the analysis of the pozzolanic activity index $\left(\mathrm{I}_{\mathrm{Ca}(\mathrm{OH}) 2}\right)$ for MFSCBA was $607 \mathrm{mg}$ of $\mathrm{Ca}(\mathrm{OH})_{2}$ per gram, with $\sigma=11$ and confidence interval estimated to be between 587.7 and $627.7 \mathrm{mg}$ of $\mathrm{Ca}(\mathrm{OH})_{2}$ per gram. It is worth noting that the value obtained with MFSCBA is higher than the minimum recommended by Raverdy et al. [37], which is $436 \mathrm{mg}$ of $\mathrm{Ca}(\mathrm{OH})_{2}$ per gram.

The results of the statistical confidence intervals obtained show that the reproducibility projections for new results, with $95 \%$ confidence provided by Student's $t$-test, reproduced values with satisfactory pozzolanic performances for MFSCBA. As the data were in agreement, a triplicate was not necessary.

The result of the fixation index endorses the hypothesis that the oxides present, in fact, contributed to the formation of calcium silicate hydrate in Mmf. This result is higher than $\mathrm{I}_{\mathrm{Ca}(\mathrm{OH}) 2}$ obtained by Filho [42], which is $569 \mathrm{mg}$ of $\mathrm{Ca}(\mathrm{OH})_{2}$ per gram for the fly sugarcane bagasse ash sample, which had amorphous structural characteristics. Cordeiro et al. [8] obtained $736 \mathrm{mg}$ of $\mathrm{Ca}(\mathrm{OH})_{2}$ per gram with the same ash.

In view of this information, the $\mathrm{I}_{\mathrm{Ca}(\mathrm{OH}) 2}$ of $607 \mathrm{mg}$ of $\mathrm{Ca}(\mathrm{OH})_{2}$ per gram for the MFSCBA sample represents a satisfactory result when compared to other results of residues evaluated as pozzolanic, especially in comparisons made with SCBA.

3.5. The Potential Use of fly Sugarcane Bagasse Ash as a Pozzolan in Brazil. The 2018/2019 Brazilian sugarcane harvest alone would have a production potential of up to 0.419 million tons of FSCBA, considering that $11 \%$ of all the ashes generated as a result of bagasse burning is estimated to be fly sugarcane bagasse ash $[14,16]$. With the use of the air jet milling technology in ash micronization proposed in this study, up to 0.398 million tons of MFSCBA could be obtained. This amount of MFSCBA would reduce up to $0.7 \%$ of Portland cement consumption in relation to the 57 million tons consumed in Brazil in 2016, merely by using the MFSCBA as a pozzolanic addition [44]. According to Fairbain et al. [13], this volume of MFSCBA would allow for the effective reduction of 137.919 thousand tons of $\mathrm{CO}_{2}$ emissions. However, it is important to develop new studies on FSCBA micronization using air jet mills on an industrial scale, and such studies would have to focus on the acquisition of processing lines to meet the estimated demand.

If the prospected volume of fly sugarcane bagasse ashes was prepared as a green pozzolanic material to partially replace $25 \%$ of Portland cement mass, this would lead to a production of up to 1.592 million tons of Portland cement of this new composite class in the current sugarcane harvest. This amount of cement dosed in concretes that present reference consumption around $400 \mathrm{~kg}$ of cement per cubic meterwould provide the production of up to 3.980 million cubic meters of green concrete. This volume of concrete would suffice to build as many as 49 Maracanã stadiums or 127 New World Trade Center complexes [40, 45, 46].

Partnerships in areas such as preparation, commercialization, and distribution of fly sugarcane bagasse ash could be established based on mutual interest between the sugarcane mills and Portland cement composite factories. To that effect, it is recommended that a cost-benefit ratio 


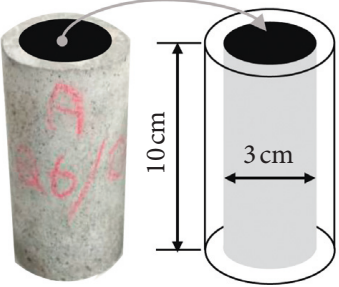

(a)

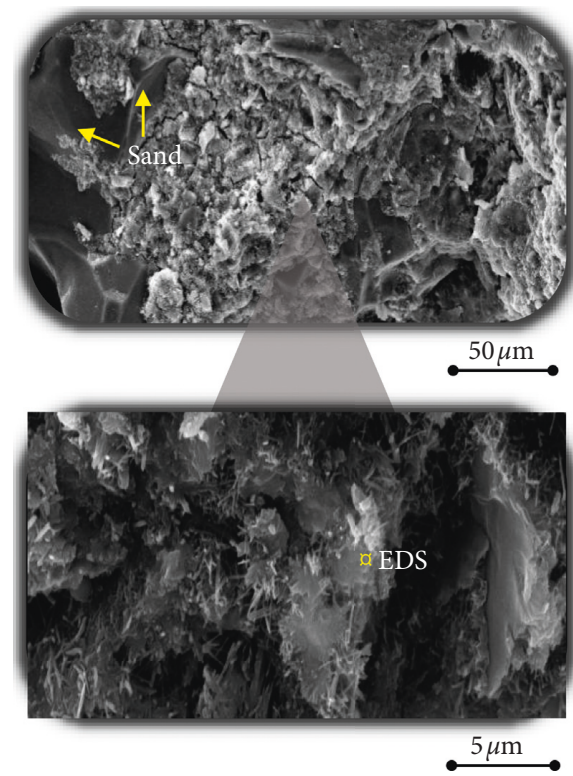

(c)

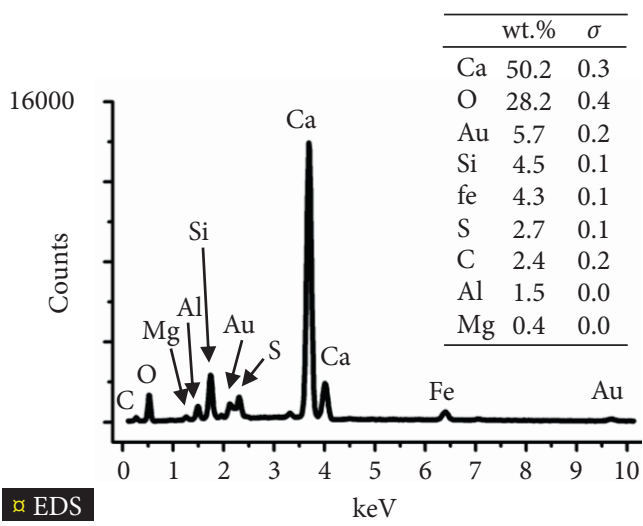

Mortar Mref

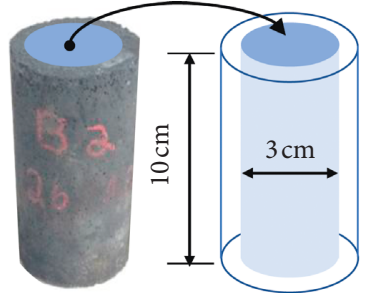

(b)

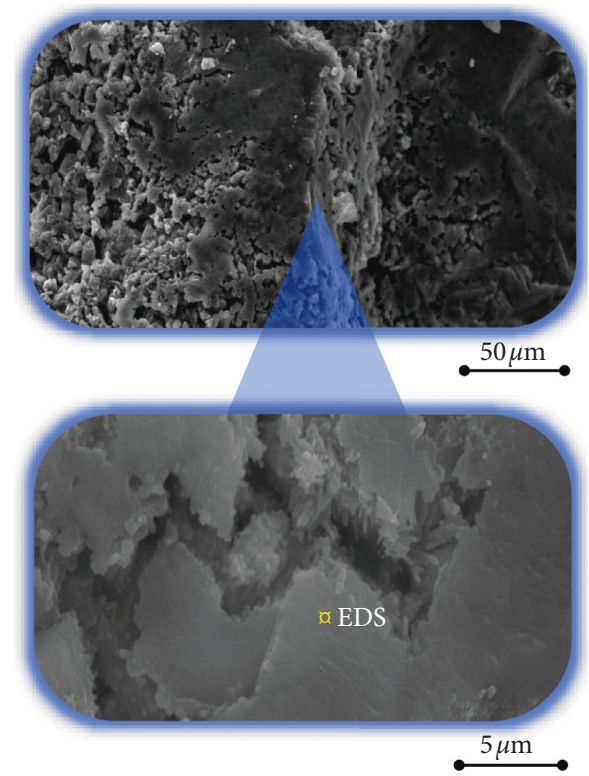

(d)

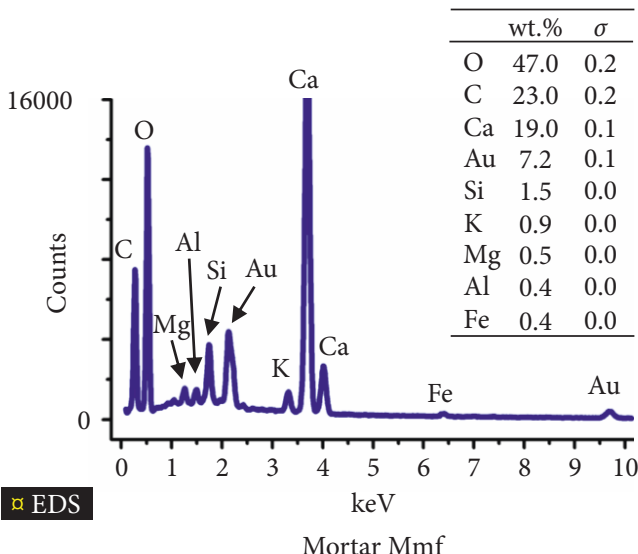

(f)

FIGURE 4: Unmolded mortar specimens after curing at 28 days and SEM/EDS images. (a) Mref with indication of sampling point area, (b) Mmf with sampling point area, (c) SEM micrographs for Mref, (d) SEM micrographs for Mmf, (e) SEM/EDS images for Mref, and (f) SEM/ EDS images for Mmf.

analysis regarding the sharing of return flows of logistics routes used in the distribution of the respective outputs be made, among other possibilities. The maximum sugarcane bagasse FSCBA projection generated in the mills in the states of São Paulo, Minas Gerais, Goiás, Mato Grosso do Sul, and Paraná, which will represent $88 \%$ of the $2018 / 2019$ (2018) national harvest, could be absorbed by the 37 (42\%) cement factories located in these states. Kurda et al. [47] report that environmental impacts can be reduced, even considering long distances between coal power and concrete plants. They emphasize that the increase in the use of coal ash reduces the overall impacts of the production chains involved.

Finally, it is noted that the addition of MFSCBA to Portland cement is an excellent alternative to reduce $\mathrm{CO}_{2}$ emissions per ton produced. Therefore, the reduction mentioned in this study would result in a great positive environmental impact, given that the cement industry is the second largest $\mathrm{CO}_{2}$ emitter. 


\section{Conclusions}

The innovative micronization of FSCBA using air jet mills allowed for the development of a solution for the use of milling fly sugarcane bagasse ash to produce green pozzolana. The main highlights were as follows:

(1) Air jet milling proved to be a technically viable and efficient alternative for the FSCBA micronization to achieve the granulometric requirements established in pozzolanic studies.

(2) The $120 \%$ IDP28 indicator and $\mathrm{I}_{\mathrm{Ca}(\mathrm{OH}) 2}$ of $607 \mathrm{mg}$ of $\mathrm{Ca}(\mathrm{OH})_{2}$ per gram confirmed the existence of pozzolanic activity in MFSCBA, with no use of reburning thermal treatment.

(3) The expressive result for MFSCBA's IDP28 indicator emphasizes that MFSCBA pozzolanic activity with a maximum dimension of $30 \mu \mathrm{m}$ increased the mortar axial compressive strength by $20 \%$. SEM images evidenced the suggestive cohesive formation of particles originated from the pozzolanic activity process, as well as oxide hydration of the cement.

All these actions can lead to advances that address social and environmental responsibilities related to the application of agro-industrial residues in the production of Portland cement. Furthermore, this initiative could help Brazil stand out in terms of $\mathrm{CO}_{2}$ emissions control practices related to Portland composite cement production, complying with national and international legislation.

\section{Data Availability}

The data used to support the findings of this study are available from the corresponding author upon request.

\section{Conflicts of Interest}

The authors herein declare that the publication of this paper will not lead to any conflicts of interest.

\section{Acknowledgments}

The authors would like to thank CAPES for the incentive given to the researchers as well as to the laboratory of civil construction materials (DEC-UEM). In addition, the authors would like to thank BASF S/A, Brazil, for sponsoring our additive and Usaçúcar Group for all the support and SCBA donation.

\section{References}

[1] C. Shi, A. F. Jiménez, and A. Palomo, "New cements for the 21st century: the pursuit of an alternative to Portland cement," Cement and Concrete Research, vol. 41, no. 7, pp. 750-763, 2011.

[2] P. K. Mehta and P. J. M. Monteiro, Concreto: Microestrutura, Propriedades E Materiais, Ibracon, São Paulo, Brazil, 2nd edition, 2014.

[3] IEA-International Energy Agency, Cement Technology Roadmap Plots Path to Cutting $\mathrm{CO}_{2}$ Emissions 24\% by 2050,
International Energy Agency, Paris, France, 2018, https://www. iea.org/newsroom/news/2018/april/cement-technology-road map-plots-path-to-cutting-co2-emissions-24-by-2050.html.

[4] P. K. Mehta, Reducing the Environmental Impact of Concrete: Concrete can be Durable and Environmentally Friendly, Concrete International, Farmington Hills, MI, USA, 2001, http://ecosmartconcrete.com/docs/trmehta01.pdf.

[5] J. Yu, D. K. Mishra, C. Wu, and C. K. Leung, "Very high volume fly ash green concrete for applications in India," Waste Management \& Research, vol. 36, no. 6, pp. 520-526, 2018.

[6] Y. R. Loh, D. Sujan, M. E. Rahman, and C. A. Das, "Sugarcane bagasse-the future composite material: a literature review," Resources, Conservation and Recycling, vol. 75, pp. 14-22, 2013.

[7] M. M. N. S. Soares, F. S. J. Poggiali, A. C. S. Bezerra, R. B. Figueiredo, M. T. P. Aguilar, and P. R. Cetlin, "The effect of calcination conditions on the physical and chemical characteristics of sugar cane bagasse ash," Rem: Revista Escola de Minas, vol. 67, no. 1, pp. 33-39, 2014.

[8] G. C. Cordeiro, R. D. Toledo Filho, and E. D. M. R. Fairbairn, "Caracterização de cinza do bagaço de cana-de-açúcar para emprego como pozolana em materiais cimentícios," Química Nova, vol. 32, no. 1, pp. 82-86, 2009.

[9] R. G. Delalibera, A. P. Sarmento, B. C. S. Lopes, and A. F. S. De Britto, "Análise da viabilidade da utilização da cinza de bagaço de cana-de-açúcar como substituição parcial do cimento portland," REEC-Revista Eletrônica de Engenharia Civil, vol. 9, no. 3, pp. 32-40, 2014.

[10] A. Bahurudeen and M. Santhanam, "Influence of different processing methods on the pozzolanic performance of sugarcane bagasse ash," Cement and Concrete Composites, vol. 56, pp. 32-45, 2015.

[11] B. R. Stanmore, "Generation of energy from sugarcane bagasse by thermal treatment," Waste and Biomass Valorization, vol. 1, no. 1, pp. 77-89, 2010.

[12] S. N. Joglekar, A. P. Tandulje, S. A. Mandavgane, and B. D. Kulkarni, "Environmental impact study of bagasse valorization routes," Waste and Biomass Valorization, pp. 112, 2018.

[13] E. M. R. Fairbairn, B. B. Americano, G. C. Cordeiro, T. P. Paula, R. D. T. Filho, and M. M. Silvoso, "Cement replacement by sugar cane bagasse ash: $\mathrm{CO}_{2}$ emissions reduction and potential for carbon credits," Journal of Environmental Management, vol. 91, no. 9, pp. 1864-1871, 2010.

[14] L. Y. C. P. Hojo, Análise da Atividade Pozolânica da Cinza Volante do Bagaço de Cana-de-Açúcar Para Substituição Parcial do Cimento Portland, Dissertation, State University of Maringá, Maringá, Brazil, 2014.

[15] Fiesp/Ciesp-Federação das Indústrias do Estado de São Paulo/ Centro das Indústrias do Estado de São Paulo, Ampliação da Oferta de Energia Através da Biomassa, Fiesp/Ciesp - Federação das Indústrias do Estado de São Paulo/Centro das Indústrias do Estado de São Paulo, Diadema, Brazil, 2012, http://www.fiesp. com.br/indices-pesquisas-e-publicacoes/ampliacao-da-ofertade-energia-atraves-de-biomassa/.

[16] Conab-Companhia Nacional de Abastecimento, Acompanhamento da Safra Brasileira: Cana-de-Açúcar. Terceiro Levantamento da Safra 2018/2019, Dezembro, Conab-Companhia Nacional de Abastecimento, Rondônia, Brazil, 2018, https:/www.conab.gov.br/component/k2/item/ download/23678_459b56cfa84b956c7de6561d4fedc5eb.

[17] NBR 12653, Pozzolanic Materials-Requirements, Associação Brasileira de Normas Técnicas (ABNT), Rio de Janeiro, Brazil, 2014. 
[18] ASTM C618-17a, Standard Specification for Coal Fly Ash and Raw or Calcined Natural Pozzolan for Use in Concrete, ASTM International, West Conshohocken, PA, USA, 2017.

[19] R. Walker and S. Pavía, "Physical properties and reactivity of pozzolans, and their influence on the properties of limepozzolan pastes," Materials and Structures, vol. 44, no. 6, pp. 1139-1150, 2011.

[20] R. Embong, N. Shafiq, A. Kusbiantoro, and M. F. Nuruddin, "Effectiveness of low-concentration acid and solar drying as pre-treatment features for producing pozzolanic sugarcane bagasse ash," Journal of Cleaner Production, vol. 112, pp. 953-962, 2016.

[21] V. Ríos-Parada, V. G. Jiménez-Quero, P. L. Valdez-Tamez, and P. Montes-García, "Characterization and use of an untreated Mexican sugarcane bagasse ash as supplementary material for the preparation of ternary concretes," Construction and Building Materials, vol. 157, pp. 83-95, 2017.

[22] Micro Service-micronização e processos (2018) Moagem de minérios, Micro Service, Diadema, São Paulo, Brazil, http://www. microservices.com.br/moagem-minerios.

[23] NBR 7215, Portland Cement-Determination of Compressive Strength, Associação Brasileira de Normas Técnicas (ABNT), Rio de Janeiro, Brazil, 1996.

[24] NBR 11578, Portland Composite Cement-Specification, Associação Brasileira de Normas Técnicas (ABNT), Rio de Janeiro, Brazil, 1991.

[25] NBR 7214, Standard Sand for Cement Tests-Specification, Associação Brasileira de Normas Técnicas (ABNT), Rio de Janeiro, Brazil, 2015.

[26] NBR 15900-1, Mixing Water for Concrete Part 1: Requirements, Associação Brasileira de Normas Técnicas (ABNT), Rio de Janeiro, Brazil, 2009.

[27] NM 248, Aggregates-Sieve Analysis of Fine and Coarse Aggregates, Associação Brasileira de Normas Técnicas (ABNT), Rio de Janeiro, Brazil, 2003.

[28] NM 52, Fine Aggregate-Determination of the Bulk Specific Gravity and Apparent Specific Gravity, Associação Brasileira de Normas Técnicas (ABNT), Rio de Janeiro, Brazil, 2009.

[29] NBR 5752, Pozzolanic Materials-Determination of the Performance Index with Portland Cement at 28 Days, Associação Brasileira de Normas Técnicas (ABNT), Rio de Janeiro, Brazil, 2014.

[30] NBR 15895, Pozzolanic materials-Determination of Calcium Hydroxide Fixed-Modified Chapelle's Method, Associação Brasileira de Normas Técnicas (ABNT), Rio de Janeiro, Brazil, 2010.

[31] ASTM C109/C109M-12, Standard Test Method for Compressive Strength of Hydraulic Cement Mortars Using $50 \mathrm{~mm}$ Cube Specimens, ASTM International, West Conshohocken, PA, USA, 2011.

[32] ASTM C1437-7, Standard Test Method for Flow of Hydraulic Cement Mortar, ASTM International, West Conshohocken, PA, USA, 2007.

[33] ASTM C311-11b, Standard Test Methods for Sampling and Testing Fly Ash or Natural Pozzolans for Use in PortlandCement Concrete, ASTM International, West Conshohocken, PA, USA, 2011.

[34] S. M. S. Kazmi, M. J. Munir, I. Patnaikuni, and Y.-F. Wu, "Pozzolanic reaction of sugarcane bagasse ash and its role in controlling alkali silica reaction," Construction and Building Materials, vol. 148, pp. 231-240, 2017.

[35] NM 25, Pozzolanic Materials-Determination of Available Reactive Alkalis, Associação Brasileira de Normas Técnicas (ABNT), Rio de Janeiro, Brazil, 2003.
[36] D. C. Montgomery and G. C. Runger, Estatística Aplicada e Probabilidade Para Engenheiros, Wiley, Hoboken, NJ, USA, 4th edition, 2009.

[37] M. Raverdy, F. Brivot, A. M. Paillère, and R. Dron, "Appréciation de l"activité pouzzolanique des constituants secondaires," in Proceedings of the 7e Congrès International de la Chimie des Ciments, pp. IV36-IV41, Paris, France, December 1980.

[38] V. P. Della, I. Khun, and D. Hotza, "Caracterização de cinza de casca de arroz para uso como matéria-prima na fabricação de refratários de sílica," Quím Nova, vol. 24, no. 6, pp. 778-782, 2001.

[39] G. A. Lager, J. D. Jorgensen, and F. J. Rotella, "Crystal structure and thermal expansion of $\alpha$-quartz $\mathrm{SiO}_{2}$ at low temperatures," Journal of Applied Physics, vol. 53, no. 10, pp. 6751-6756, 1982.

[40] R. G. D. M. Filho, D. A. Longhi, R. C. T. de Souza et al., "Selfcompacting mortar with sugarcane bagasse ash: development of a sustainable alternative for Brazilian civil construction," Environment, Development and Sustainability, 2018.

[41] S. A. Lima and J. A. Rossignolo, "Estudo das características químicas e físicas da cinza da casca da castanha de caju para uso em materiais cimentícios," Acta Scientiarum Technology, vol. 32, no. 4, pp. 383-389, 2015.

[42] S. T. M. Filho, Utilização da Cinza Leve e Pesada do Bagaço de Cana-de-Açúcar Como Aditivo Mineral na Confecção de Blocos de Concreto Para Pavimentação, Dissertation, State University of Maringá, Maringá, Brazil, 2015.

[43] S. K. Melo, Estudo da Formação da Etringita Tardia em Concreto por Calor de Hidratação do Cimento, Dissertation, Federal University of Goiás, Goiás, Brazil, 2010.

[44] Snic-Sindicato Nacional das Industrias de Cimento, Dados do Setor: Produção de Cimento, Snic-Sindicato Nacional das Industrias de Cimento, Rio de Janeiro, Brazil, 2016, http:// snic.org.br/numeros-do-setor.php.

[45] A. Santos, Maracanã Encolhe, Mas Ganha Inovações E Sustentabilidade, Massa Cinzenta, Rio de Janeiro, Brazil, 2011, http://www.cimentoitambe.com.br/maracanaencolhe-masganha-inovacoes-e-sustentabilidade.

[46] A. Santos, Novo World Trade Center Prioriza o Concreto, Massa Cinzenta, São Carlos, Brazil, 2012, http://www.cimentoitambe. com.br/novo-world-tradecenter-prioriza-o-concreto/.

[47] R. Kurda, J. D. Silvestre, and J. de Brito, "Life cycle assessment of concrete made with high volume of recycled concrete aggregates and fly ash," Resources, Conservation and Recycling, vol. 139, pp. 407-417, 2018. 


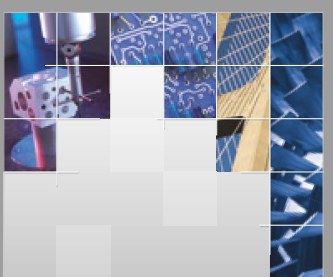

\section{Enfincering}
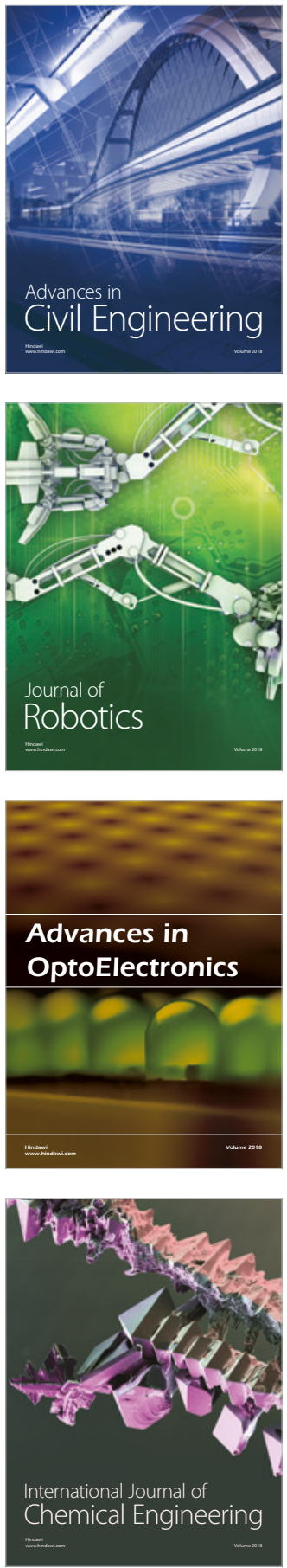

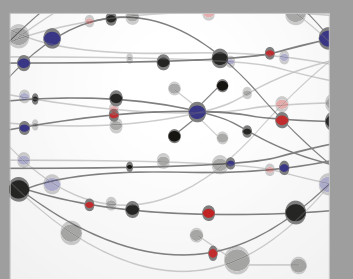

\section{Rotating \\ Machinery}

The Scientific World Journal

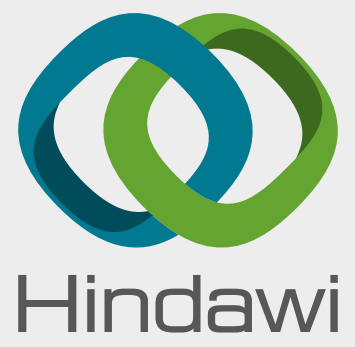

Submit your manuscripts at

www.hindawi.com
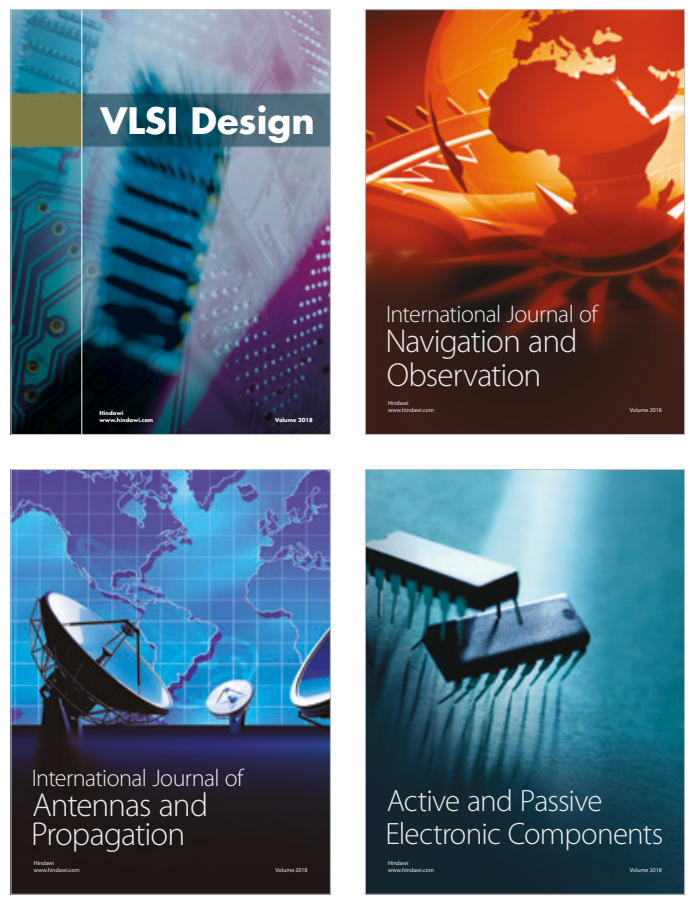
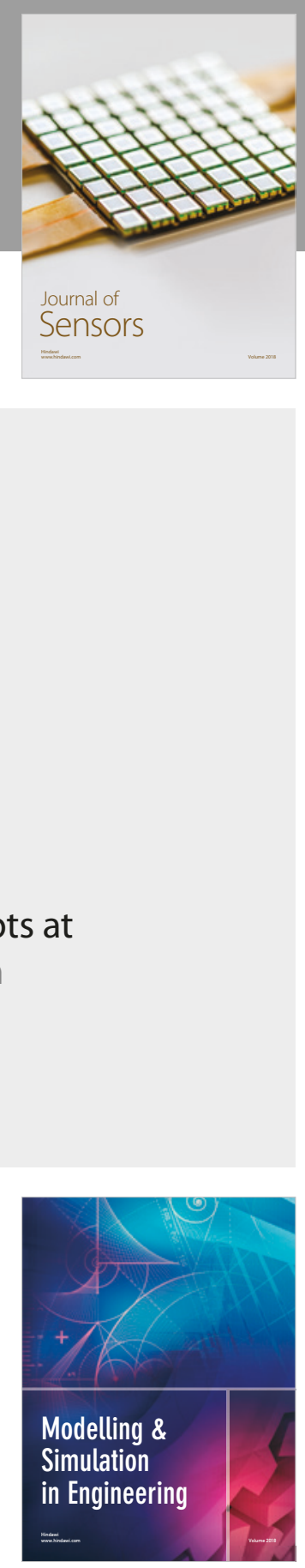

\section{Advances \\ Multimedia}
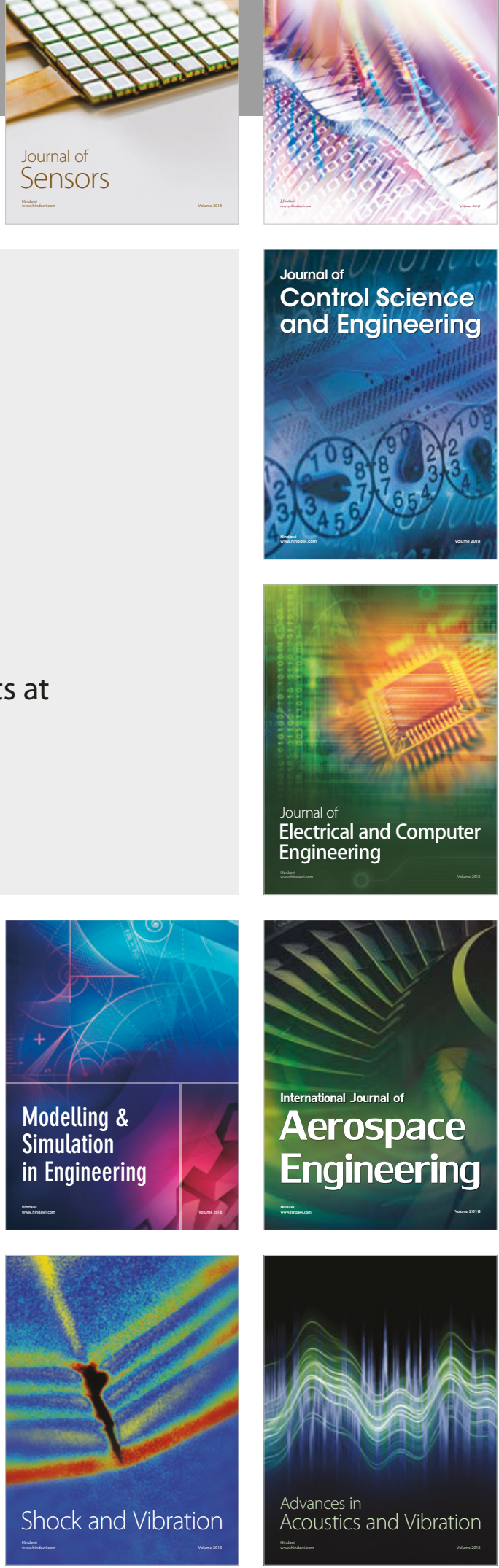